\title{
Analysis of the Etiological Structure of Subclinical Mastitis in the South of the Tyumen Region
}

\author{
Kozlova S.V. \\ Northern Trans-Ural State Agricultural University, \\ Tyumen, Russia, \\ E-mail: kozlovasv@gausz.ru
}

\author{
Krasnolobova E.P. \\ Northern Trans-Ural State Agricultural University, \\ Tyumen, Russia, \\ E - mail: krasnolobovaep@gausz.ru
}

\author{
Veremeeva S.A. \\ Northern Trans-Ural State Agricultural University, \\ Tyumen, Russia, \\ E-mail: veremeevasa@gausz.ru
}

\begin{abstract}
The article analyses the data of bacteriological studies of milk taken from dairy cattle for mastitis identification in 2015-2017. The studies involved standard methods to identify germ cultures and investigate their morphological and biological parameters determining the species of the germs. Microbiological methods of investigation were done in compliance with regulatory document "Guidelines to bacteriological study of milk and cow udder secretion" no. 115-69. As a result of bacteriological studies, positive mastitis tests in milk were obtained, a new composition of pathogens of positive samples was determined, the etiological mastitis structure was analyzed over the last recent years. The dynamics of the etiological mastitis structure indicators over 2015 2017 was studied. The analysis of obtained results established that in the south of Tyumen region over the last three years, the number of positive milk test for mastitis decreased twice; the etiological structure of identified subclinical mastitis of productive animals included three types of bacteria, E. coli, St. aureus, Ps. aeruginosa, which were identified both in associated state and as monocultures. The main exciter of subclinical mastitis over the last three years was Staphylococcus aureus with the percentage in the etiological structure of $\mathbf{4 9 . 2 \%}$.
\end{abstract}

Keywords-mastitis, diagnostics, milk, microbiological investigation methods, microorganisms, etiological structure.

\section{INTRODUCTION}

Mastitis is quite widely spread in livestock rearing not only in Russia, but also in near and far abroad.

In European countries, the mastitis incidence reaches 12 $40 \%$, in USA up to $40 \%$.

In near abroad the spread of the disease fluctuates the same and, depending on geographical location, can reach $60 \%$ (in Asian countries).

In Russia, about $50 \%$ of total number of culled animals are cows with udder inflammation and hypomastia of various etiology. The subclinical mastitis among other forms amounts to $63 \%$ on average.

The inflammatory of lacteous gland for the majority of animals occurs several times a year. The mastitis can occur in any age and manifests less frequently during three first lactations. The occurrence of subclinical mastitis increases with age; for animals older than 8 years it amounts to $94.1 \%$.

This disease appears in any season of the year; the maximum percentage is in February-April (about 30\%), the minimum is in June-August (11\%). Subclinical mastitis more frequently occurs in April and November (13\%) and less frequently in August and September (about 6\%) [2, 12].

Main losses from mastitis are decreased milk yield and disability to maximally use the genetic potential of dairy animal yield. Even after successful treatment of mastitis, in majority of cases it leads to hypogalactia or agalactia, while the expenses for the treatment and losses from culling the animals are equal to the cost of 700 liters of milk lost from one cow per year [5, $7,10,11]$.

Subclinical mastitis causes decreased indicators of food and technological value of milk. Milk becomes dangerous in term of microbiology. For instance, in the previous century, the international symposium on infections in Varna has put cow mastitis on the first place in terms of danger for human health.

Early diagnostics of latent mastitis prevents the development of irreversible pathologic processes in the mammary gland, which preserves sanitary quality of milk and its technological properties, prolongs the period of economical usage of productive animals $[1,6,9,14]$.

Timely diagnostics of mastitis enables effective treatment of this widely spread disease and, which is particularly important, development of necessary prophylactic measures. Since the subclinical forms of mastitis are spread more than clinical ones, the solution of the problem of subclinical mastitis early detection is of substantial importance for national economy.

Taking into account the role of microbial factor in the development of mammary gland pathology, the researchers constantly report the appreciable sanitary and epidemiological significance of mastitis, especially in lactation cows. Currently, it is hard to distinguish the limit in determination of pathogenic properties of certain microorganisms. They are broadly spread, 
can proliferate very fast, and the majority of microorganisms become undemanding to the sources of food and energy. Many microorganism that were previously regarded as opportunistic have obtained new properties and habitat and play large role in disease development, including mastitis in productive animals $[3,4,8,13,15]$.

In this connection, the research of issues of modern bacteriological diagnostics of mastitis with determination of the etiological structure remains high on the agenda.

\section{MATERIALS AND METHODS}

The work was done in the Department of anatomy and physiology of the Institute of biotechnology and veterinary at State Agrarian University of North Trans-Urals. The research part of the work was done in the microbiological department of Tyumen regional veterinary laboratory.

We have made the analysis of statistical data of bacteriological research that were made in laboratory conditions in 2015-2017.

The studies of milk samples involved standard methods to identify germ cultures and investigate their morphological and biological parameters determining the species of the germs.

Microbiological methods of investigation were done in compliance with regulatory document "Guidelines to bacteriological study of milk and cow udder secretion" no. 11569 as of 31.12. 1983 with amendment no. 432-3 as of 06. 12 . 1988 ; in force on 14.02.2018.

The bacteriological studies of the milk sample included inoculation of milk in nutrient media with consequent investigation of the biology of cultivated microorganisms. Initial inoculations were made in meat infusion agar, meat infusion broth, CODA medium, blood agar. Reinoculation of cultures to study the biology was made in beef-extract gelatin, Kitt-Tarozzi medium, Kligler medium, Kristenson medium, Endo agar, Simmons agar and others.

The isolated cultures of microorganisms were identified with due consideration of morphological parameters, cultural, biochemical and pathogenic properties.

On the basis of the comparison of morphobiological parameter of the isolated cultures with determinant data, the conclusions were made on their belonging to a specific species.

The received results of bacteriological studies were processed statistically with due consideration of average values, their margins and Student's reliability level (P) using Microsoft Excel and Biostat software.

\section{RESULTS AND DISCUSSION}

The discovery of latent mastitis with determination of the microbial etiology is possible only by laboratory diagnostics.

Increased requirements to sanitary quality of milk determine the increased number of milk samples received for bacteriological study in the veterinary laboratory of Tyumen. It was noted that in 2016, the number of milk samples brought to the laboratory had almost doubled as compared to 2015, in 2017 it increased almost 1.5 times.
The number of received milk samples and positive mastitis tests over the last three years is presented in Table 1 .

TABLE 1. NUMBER OF RECEIVED MILK SAMPLES AND POSITIVE MASTITIS TESTS IN 2015-2017

\begin{tabular}{|l|c|c|c|}
\hline \multicolumn{2}{|c|}{ Indicators } & \multicolumn{3}{|c|}{ Year } \\
\cline { 2 - 5 } & $\mathbf{2 0 1 5}$ & $\mathbf{2 0 1 6}$ & $\mathbf{2 0 1 7}$ \\
\hline $\begin{array}{l}\text { Samples tested for } \\
\text { mastitis [pcs] }\end{array}$ & 128 & 229 & 179 \\
\hline $\begin{array}{l}\text { Positive mastitis tests } \\
\text { [pcs] }\end{array}$ & 91 & 107 & 68 \\
\hline $\begin{array}{l}\text { Percentage of positive } \\
\text { tests [\%] }\end{array}$ & 71.1 & 46.7 & 38.0 \\
\hline
\end{tabular}

Data in Table 1 testify that the number of milk samples received for mastitis test increases. The maximum number (107 samples) of positive tests were determined in 2016 and their percentage amounted to $46.7 \%$. In 2015 , the number of positive tests was $91(71.1 \%)$. In 2017, the percentage of positive samples was $38 \%$.

Over the three studied years, the number of positive mastitis tests decreases.

Milk is the secretion of productive animals mammary gland. Hence, its qualitative characteristics depend on the peculiarities of functioning of not only the gland, but the organism as a whole. The structure and physiology of the mammary gland facilitate the formation of its microbiocoenosis. The number and species of microflora of productive animal mammary gland are affected by endogenic and exogenic factors.

The successful therapy and prophylaxis of subclinical mastitis depend on determination of the disease cause. The leading role in mammary gland pathology development is played by microorganisms. It is the presence of specific microorganisms which affects the specificity of pathology development. According to the statistical data, in most cases the latent mastitis bears nonspecific character. Its main excitants are sanitary indicator microorganisms.

All the afore mentioned was used to analyze the etiological structure of identified mastitis.

The analysis results over the last three years are presented in Figure 1 and Table 2.

The data in Fig. 1 demonstrate that on average over the three years, the composition of the etiological structure of identified mastitis is represented by such bacteria as E. coli, St. aureus, Ps. aeruginosa. The maximum occurrence $(49.2 \%)$ in the etiological structure is specific for Staphylococcus aureus. The minimum occurrence $(9.8 \%)$ is specific for Pseudomonas aeruginosa. 


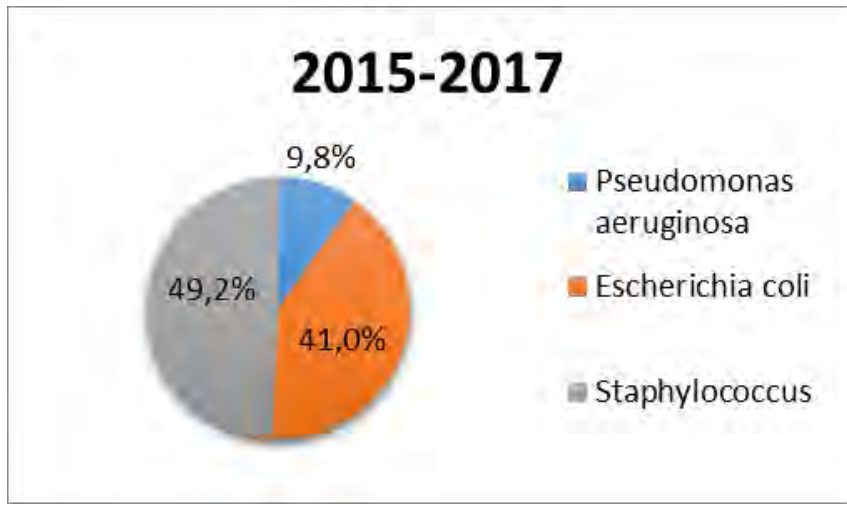

Fig. 1. Etiological structure of mastitis in 2015-2017

A number of authors report that the etiological structure of mastitis is unstable and can very under different factors. In this connection we have analyzed the etiological structure of mastitis for every studied year. The result are presented in Table 2.

TABLE 2 ETIOLOGICAL STRUCTURE OF MASTITIS IN 2015-2017

\begin{tabular}{|l|c|c|c|c|c|c|}
\hline \multirow{2}{*}{$\begin{array}{c}\text { Group of } \\
\text { microorganisms }\end{array}$} & \multicolumn{7}{|c|}{ Year } \\
\cline { 2 - 7 } & \multicolumn{2}{|c|}{2015} & \multicolumn{2}{c|}{2016} & \multicolumn{2}{c|}{2017} \\
\cline { 2 - 7 } & Total & {$[\%]$} & Total & {$[\%]$} & Total & {$[\%]$} \\
\hline St. aureus & 49 & 53.8 & 50 & 46.7 & 32 & 47.1 \\
\hline E. coli & 36 & 39.6 & 42 & 39.3 & 30 & 44.1 \\
\hline Ps. aeruginosa & 6 & 6.6 & 15 & 14.0 & 6 & 8.8 \\
\hline Total & 91 & 100 & 107 & 100 & 68 & 100 \\
\hline
\end{tabular}

The data in Table 2 tell that in 2015, the maximum occurrence in the structure of species isolated from positive mastitis milk tests is specific for cocci; the minimum occurrence is specific for pseudomonas. The same relation was identified in 2016 and 2017.

The dynamics of etiological mastitis structure in 2015-2017 is depicted in Figure 2.

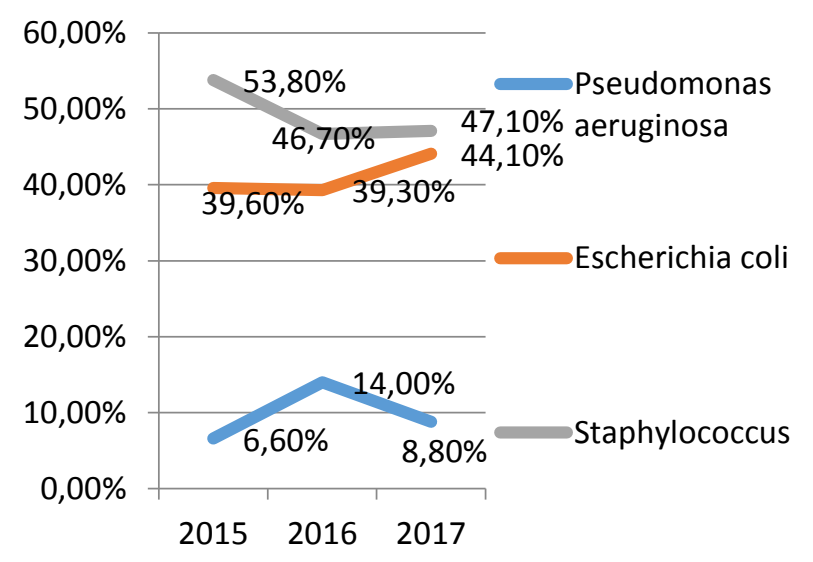

Fig. 2. Dynamics of etiological structure of mastitis in 2015-2017

The largest number of staphylococci was identified in 2015; they had the largest occurrence (53.8\%) among isolated microorganisms over the three years. In 2016 and 2017, the number of samples from which staphylococcus was isolated decreases ( $46.7 \%$ and $47.1 \%$, respectively).

The pseudomonas over the three years reached the maximum (14\%) in 2016, while in 2015 it was among minimum positive tests $(6 \%)$ over the whole studied period.

The percentage of coliform bacterium isolation from milk in 2015 and 2016 remained almost on the same level $(39.6 \%$ and $39.3 \%$ ), but in 2017 its occurrence in the etiological mastitis structure reached $44.1 \%$.

We have analyzed the mastitis milk tests obtained in July of 2017. In total, 36 samples were received: 24 from cows and 12 from goats. Among the samples, 12 were positive (33.3\%). In the positive tests we isolated Pseudomonas aeruginosa, Escherichia coli, Staphylococcus aureus.

TABLE 3. STRUCTURE OF RESULTS OF MILK MASTITIS TESTS IN JULY 2017

\begin{tabular}{|c|c|c|c|c|}
\hline $\begin{array}{c}\text { Number } \\
\text { of } \\
\text { studied } \\
\text { samples }\end{array}$ & \multirow{2}{*}{$\begin{array}{c}\text { Negative } \\
\text { tests [\%] }\end{array}$} & \multicolumn{3}{|c|}{ Isolated species [\%] } \\
\cline { 3 - 5 } & & $\begin{array}{c}\text { St. } \\
\text { aureus }\end{array}$ & E. coli & $\begin{array}{c}\text { Ps. } \\
\text { aeruginosa }\end{array}$ \\
\hline 36 & 66.6 & 11.1 & 13.8 & 8.3 \\
\hline
\end{tabular}

According to the data, from 36 tests, negative are $66.6 \%$, the percentage of E. coli is $13.8 \%$, St. aureus $11.1 \%$, Ps. aeruginosa $8.3 \%$.

The data derived after the studies of the etiological mastitis structure are given in Figure 3.

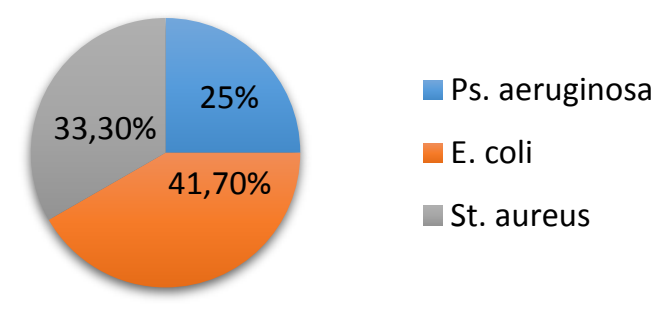

Fig. 3. Etiological mastitis structure in July 2017

The largest percentage in the etiological mastitis structure $(41.7 \%)$ is taken by coliform bacterium, the smallest $(25 \%)$ by Ps. aeruginosa. The percentage of St. aureus was $33.3 \%$.

The revealed relation of species in the etiological mastitis structure in July differs from average yearly data. While in July, the largest percentage is specific for E. coli $(41.7 \%)$, over the whole 2017 is is specific for St. aureus (47.1\%). Hence, the relation of species in the etiological mastitis structure fluctuates dependending on the season. For summer, active proliferation and accumulation in the environment is specific for E. coli. As a result, the frequency of pathologies induced by coliform bacterium, mastitis in particular, increases. 
It is reliably known that subclinical mastitis more frequently occurs in lactation cows, as compared to other productive animals.

We have made the analysis of the etiological mastitis structure with due consideration of species from which the milk samples were taken. Among 36 studied samples in July, 24 were taken from cows and 12 from goats (Figure 4).

\section{Goat milk Cow milk}

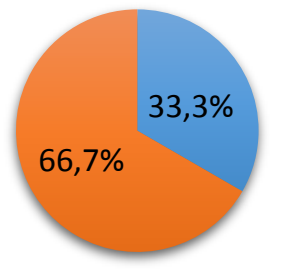

Fig. 4. Species from which milk samples for mastitis were taken

Among the studied milk samples $66.7 \%$ were taken from cows and only $33.3 \%$ from goats.

Among 24 samples of cow milk $8(33.3 \%)$ were positive and $16(66.7 \%)$ were negative.

The etiological mastitis structure for cows is depicted in Figure 5.

Ps. aeruginosa E. coli St. aureus

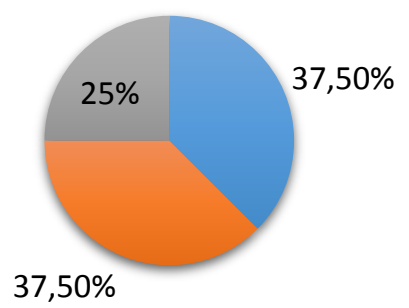

Fig. 5. Etiological mastitis structure for cows in July 2017

According to the data, the etiological mastitis structure of cows is represented by 3 bacterial species (E. coli, St. aureus, Ps. aeruginosa). The largest percentage in the structure is taken by pseudomonas $(37.5 \%)$, the smallest one is taken by staphylococcus aureus (25\%).

Among 12 samples of goat milk $4(33.3 \%)$ were positive and $8(66.7 \%)$ were negative.

The etiological mastitis structure for goats is depicted in Figure 6.

The received data tells that the etiological structure of goats includes two species (E. coli, St. aureus).
E. coli St. aureus

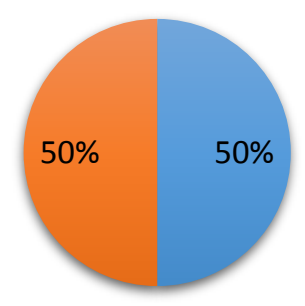

Fig. 6. Etiological mastitis structure for goats in July 2017

The percentage of isolated species in the etiological mastitis structure of goats is the same and amounts to $50 \%$.

\section{CONCLUSIONS}

The analysis of the bacteriological mastitis testing of milk taken from productive animals dwelling in the south of Tyumen region allows concluding the following.

- The number of positive mastitis tests decreases. Over the three years, the positive milk tests decreased almost twice.

- Over the three years, the etiological mastitis structure of productive animals includes three bacterial species, E. coli, St. aureus, Ps. aeruginosa, that are isolated both as associates and as monocultures.

- The main cause of subclinical mastitis is Staphylococcus aureus with the percentage in the etiological structure over the last three years of $49.2 \%$. However, this relations can change.

- The relation of species in the etiological mastitis structure of productive animals fluctuates over years and over seasons.

- The main cause of subclinical mastitis of productive animals in Tyumen region in July of 2017 is Escherichia coli; its percentage in the etiological structure is $41.7 \%$.

- Among the studied milk samples, the largest percentage $(66.7 \%)$ is taken by the milk samples from cows, and the smallest one $(33.3 \%)$ by those taken from goats

- The etiological mastitis structure of cows in July 2017 is formed by three species, E. coli, St. aureus, Ps. aeruginosa, while the main cause of subclinical mastitis is E. coli.

- The etiological mastitis structure of goats is equally formed by two species, E. coli, and St. aureus.

Since the etiological mastitis structure is composed of microorganisms that are quite widely spread and belong to sanitary indicator microorganisms, one can suggest that such situation is conditioned by the following factors: reduced resistance of animal organism, poor feeding, violation of hygienic rules and milking rules, udder trauma, violation of milk sampling rules for bacteriological studies. 


\section{References}

[1] S.S. Bala, I.V. Savina, "Diagnostika i lecheniye mastitov u korov", Uspekhi sovremennogo yestestvoznaniya, 2005, No. 10, pp. 36-37.

[2] V.S. Buyarov, M.A. Mal'tseva, N.A. Aldobayeva, "Nauchnoprakticheskoye obosnovaniye primeneniya probiotikov $\mathrm{v}$ molochnom skotovodstve i myasnom ptitsevodstve", Agrarnyy vestnik verkhnevolzh'ya, No.2 (28), 2018, pp. 79-86.

[3] L.A. Glazunova, Yu.V. Glazunov, A.A. Ergashev, "Ecologicalepizootical situation on telasiosis among large cattle in northern Ural region", Research Journal of Pharmaceutical, Biological and Chemical Sciences, 2018, Vol. 9, No. 4, pp. 1687-1693.

[4] O.N.Goncharenko et al, "Case-method in the structure of training the veterinary physician”, Astra Salvensis, 2018, Vol. 6, pp. 647-655.

[5] V. M. Zhukov, V. Yu. Kazantseva, "Osobennosti klinikomorfologicheskoy diagnostiki mastitov u korov", Altayskiy GAU, No.2 (136), 2016, pp. 114-178.

[6] V.Y. Komarov, B. L. Belkin, "Ispol'zovaniye novogo preparata «Adimast» dlya odnomomentnogo zapuska korov v sukhostoynyy period i profilaktika mastita", Altayskiy GAU, No.5 (127), 2015, pp. 107-108.

[7] Ye.O. Krupin, SH.K. Shakirov, M.Sh. Tagirov, "Dinamika fizikokhimicheskogo sostava i molochnoy produktivnosti korov pri sbalansirovannom kormlenii v zavisimosti ot genotipa", Agrarnyy vestnik verkhnevolzh'ya, No.2 (28), 2018, pp. 60-64.

[8] C.A. Sidorova et al, "State of the body of rabbits suffering from psoroptosis receiving sel-plex. Biology and Medicine", 2014, Vol. 6 , No. 3, pp. BM-043-14.

[9] M.V. Sorokin, "Terapiya mastitov", Rossiyskiy veterinarnyy zhurnal, 2006, pp. 26-27.

[10] O.A. Stolbova, Ye.G. Kalugina, "Sindrom metrit-mastit-agalaktiya u sviney", Vestnik Altayskogo gosudarstvennogo agrarnogo universiteta, 2017, No. 11 (157), pp. 132-136.

[11] O.A. Stolbova, "Effektivnost' profilakticheskikh priyemov pri mastitakh u korov v Severnom Zaural'ye", Mezhdunarodnyy nauchnoissledovatel'skiy zhurnal, 2017, No. 3-3 (57), pp. 27-30.

[12] V.G. Skopichev, V.I Yakovlev, "Private physiology", Moscow: Kolos, 2008, p. 555.

[13] M.A. Chasovshchikova, "Relationship between the genetic variants of kappa-casein and prolactin and the productive-biological characteristics of cows of the black-motley breed", Journal of Pharmaceutical Sciences and Research, 2017, Vol. 9, No. 7, pp. 1038-1044.

[14] L.A. Cherepakhina, "Kompleksnyy podkhod k profilaktike mastita u korov", Vesnik Orel GAU, No.2 (09, 2009, pp. 44-45.

[15] G.A. Yarmots, L.P. Yarmots, A.S. Ivanova, "Vliyaniye biopleksov na perevarimost' korma i molochnuyu produktivnost' korov", Glavnyy zootekhnik, 2011, No. 5, pp. 13-15. 